\title{
FOOD ADDITIVES AND CONSUMER PREFERENCES: A CROSS-CULTURAL CHOICE-BASED CONJOINT ANALYSIS
}

\author{
V. Szücsa*, L. Guerrero ${ }^{b}$, A. Claret ${ }^{b}$, M. Tarcea ${ }^{c}$, E. Szabóa and D. Bánáti ${ }^{d}$ \\ ${ }^{a}$ Department of Technology and Food Chain Analysing, National Agricultural Research and Innovation Centre - \\ Food Science Research Institute, H-1022 Budapest, Herman Ottó út 15. Hungary \\ bIRTA - Food Technology, XaRTA. Finca Camps i Armet, E-17121 Monells. Spain \\ ${ }^{\mathrm{c}}$ University of Medicine and Pharmacy, 38 Gheorghe Marinescu street, 540139 Targu-Mures. Romania \\ ${ }^{\mathrm{d}}$ International Life Sciences Institute Europe, Av. E. Mounier 83, box 6, 1200 Brussels. Belgium
}

(Received: 8 April 2014; accepted: 15 July 2014)

\begin{abstract}
Important differences have been reported in several countries about the level of concern in connection with food additives. In order to better understand the consumer preferences related to foodstuffs containing food additives, five hypotheses were tested with the help of a choice-based conjoint analysis. The study was performed in three European countries (Hungary, Romania, and Spain) having different risk perceptions concerning food additives. Two "model foodstuffs" were involved in the analysis: pre-packed sliced cheese (natural image) and chips (artificial image). For the creation of the conjoint cards, three attributes were selected: "preservatives" (natural/artificial), "packaging gases" (contains/does not contain) and "price" (average based on market data/ $+10 \% /+20 \%$ ). Results were collected via Internet simultaneously and a total of 500 valid questionnaires were received in case of pre-packed cheese and 468 regarding chips. In the analysed countries "preservatives" had an outstanding importance - mainly in Hungary and Romania-, while "packaging gases" got lower importance during the shopping intention. "Natural preservatives" very positively contributed to the choosing of both pre-packed sliced cheese and chips. High level of willingness to pay was not observed, as well as the "price" was less important factor than the additives. Comparison of the data from three countries showed notable differences, which can determine the direction of the product planning and development.
\end{abstract}

Keywords: food additives, preservatives, packaging gases, conjoint analysis

Due to the changing lifestyle, domestic food production is continuously pushed into the background and the importance of food industry is marked up at the same time. In order to fulfil consumers' multiple demands (foodstuffs have to be convenient, tasty, pleasant, healthy, fresh, safe, and affordable at the same time), and to satisfy the needs of the food industry (like the extended product storage life for the easy to plan and comfortable logistics and the cost effective food production) utilization of food additives became common. However, nowadays there are more and more people who try to avoid foodstuffs containing food additives and try to consume products supposed to be "natural". Rising popularity of natural components can be due to the fact that food additives are considered as unhealthy (TARNAVÖLGYI, 2003; Honkanen \& Voldens, 2006; McCarthy et al., 2007; Unusan, 2007; Medián, 2009; Ozer et al., 2009; MARIÁN et al., 2011) substances, which can cause cancer (SCHAFER et al., 1993; WARDLE et al., 2001) and allergy reactions (MARIÁN et al., 2011) in humans. At the same time, consumers are sceptic about the utilization of food additives, they are not aware of their advantages. Consumers think that they are just for the process of products, to increase the producers' profit, they are not safe enough (SHIM et al., 2011), their utilization is too excessive

* To whom correspondence should be addressed.

Phone:+36-1-796-0423; fax: +36-1-796-0449; e-mail: v.szucs@cfri.hu

0239-3006/\$20.00 @ 2014 Akadémiai Kiadó, Budapest 
(Kajanne \& Pirttilä-Backman, 1999) and unnecessary (Kajanne \& Pirttilä-Backman, 1999). Along with these, the presence of food additives is moderately important factor during the consumers' food choice (Food Standards Australia New Zealand, 2003; Honkanen \& VOLDENS, 2006; FARr et al., 2007; UnUSAN, 2007, JEVŠniK et al., 2008; GRUNERT et al., 2010), near other factors like sensory attributes, price, freshness, date of durability, good quality, and health (Lappalainen et al., 1998; HonKanen \& Voldens, 2006; GFK, 2007; JeVŠniK et al., 2008; SHIM et al., 2011). It is noteworthy, that Hungarian consumers pay higher attention to food additives during their shopping decisions compared to other countries (GFK, 2007; MARián et al., 2011; MARKETING INFO, 2013).

Results of the EUROBAROMETER (2010) survey showed that in Hungary the rate of concern about food additives was high (81\%), while in Romania (74\%) and Spain (54\%) much lower. Furthermore, a high rate of the Hungarian (82\%) and Romanian (90\%) consumers thought that the foodstuffs and drinks could contain chemicals (EUROBAROMETER, 2013) and for these consumers the avoidance of foodstuffs containing additives is an important element of "eating healthy diet" (Eurobarometer, 2006). Less Spanish consumer thought that chemicals can be found in foods and drinks (75\%) (EUROBAROMETER, 2013) and for them the avoidance of food additives is not a basic element at all when they are thinking of healthy diet (Eurobarometer, 2006b). The latter observations can be due to the fact that Spanish consumers are satisfied with their consumption habits (GuERrERo et al., 2012) and they consider that their Mediterranean diet is healthy enough (CARrillo et al., 2011).

On the basis of the literature review and the previous studies of the authors, the aim of this study was to test five hypotheses on the preference of foodstuffs from the point of view of food additive content in three European countries: Hungary, Spain, and Romania. The analysed hypotheses were:

1. The factor "preservative" is the most important factor, among those studied, in the shopping intention (Hypothesis 1).

2. "Packaging gases" have different importance in the shopping intention in the analysed countries (Hypothesis 2).

3. "Natural preservatives" are preferred in the analysed countries and foodstuffs (Hypothesis 3).

4. Consumers are willing to pay an "extra" for foodstuffs containing natural preservatives (Hypothesis 4).

5. Important differences exist between the studied countries regarding concern about food additives (Hypothesis 5).

\section{Materials and methods}

\subsection{Conjoint analysis design}

Steps of the conjoint analysis were designed by taking into consideration the national (LAKNer, 2002) and the international (RyAn \& FARRAR, 2000; NorTH \& DE Vos, 2002) studies. Considering results of the previous studies (SzÜCS et al., 2012), three factors were chosen for the conjoint study: "preservatives" (artificial/natural), "packaging gases" (contains/does not contain), and "price" (average+10\%/average $+20 \%$ ). Average prices were determined on the basis of market data. Conjoint cards of two "model foodstuffs" were created and used to simulate a shopping situation. One foodstuff was expected to have high additive content (chips) and the other was expected to have low additive content (pre-packed sliced cheese) 
according to consumers' perception (TARNAVÖLgYI, 2009; SzÜCS \& BÁNÁTI, 2010). For the choice-based conjoint study, six cards were chosen (Table 1) according to an orthogonal design. One additional card was added to illustrate a "standard" foodstuff (contains artificial preservatives and packaging gases on average price). In the choice sets each card was always compared to the "standard" card of foodstuffs, and participants had to decide which product they preferred better (the "both" and the "none" answers were also offered). The pairs were set out in a fixed order.

Table 1. Applied conjoint cards for the two-model foodstuffs

\begin{tabular}{|c|c|c|c|c|c|c|c|}
\hline \multirow[t]{2}{*}{ Cards } & \multicolumn{2}{|c|}{ Preservatives } & \multicolumn{2}{|c|}{ Packaging gases } & \multicolumn{3}{|c|}{ Price } \\
\hline & Artificial & Natural & Contains & $\begin{array}{c}\text { Does not } \\
\text { contain }\end{array}$ & $+10 \%$ & $+20 \%$ & Average \\
\hline "Standard" & $X$ & & $\mathrm{X}$ & & & & $\mathrm{X}$ \\
\hline 1 & & $\mathrm{X}$ & & $\mathrm{X}$ & $\mathrm{X}$ & & \\
\hline 2 & & $X$ & & $X$ & & $X$ & \\
\hline 3 & $\mathrm{X}$ & & & $\mathrm{X}$ & $\mathrm{X}$ & & \\
\hline 4 & & $\mathrm{X}$ & $\mathrm{X}$ & & $\mathrm{X}$ & & \\
\hline 5 & $X$ & & & X & & X & \\
\hline 6 & & $\mathrm{X}$ & $\mathrm{X}$ & & & $\mathrm{X}$ & \\
\hline
\end{tabular}

\subsection{Conjoint analysis data collection and statistical analysis}

Results were collected via Internet. A total of 216/210 (pre-packed sliced cheese/chips) valid questionnaires were received in Hungary, 154/157 in Spain, and 130/101 in Romania (in total 500 for pre-packed sliced cheese and 468 for chips). Although - comparing to other quantitative methods - the samples were not representative and the number of the participants were not so high, conjoint analysis can give relatively informative results from the respondents shopping decisions (LAKNER, 2002). Estimation of the utility values and the relative importance that participants gave to the selected attributes during the foodstuff selection was performed with the Conjoint module from the XLSTAT statistical software. Comparison of the utility values within the levels - depending on their number - was carried out with the help of $t$-test and ANOVA (Tukey Post-hoc test) $(\mathrm{P} \leq 0.05)$, as well as amongst the countries by independent two-sample $t$-test $(\mathrm{P} \leq 0.05)$.

\section{Results and discussion}

\subsection{Relative importance and utility values of pre-packed sliced cheese}

In all countries "preservatives" was the most important factor in the purchase intention (Hypothesis 1 is confirmed) (Fig. 1). "Packaging gases" was more important factor for the Hungarian and Spanish respondents than for the Romanians (Hypothesis 2 is confirmed). Furthermore, for the Hungarian and Spanish participants "packaging gases" and "price" had pretty much the same importance when choosing a pre-packed cheese. "Price" appeared to be a less important factor for the Hungarian consumers than for the participants from the other two countries. 


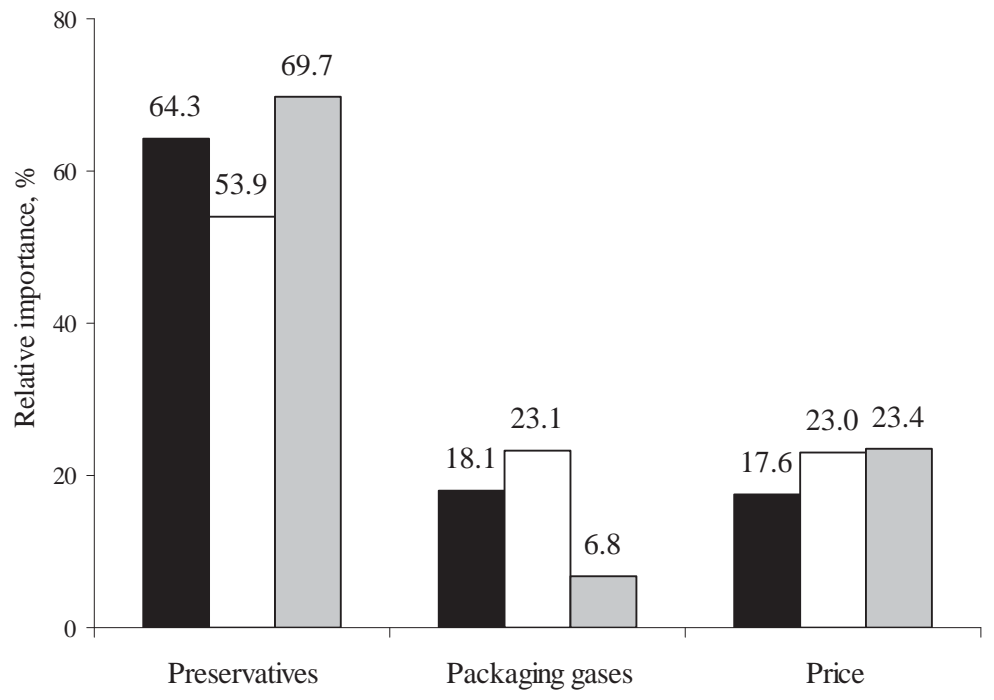

Fig. 1. Relative importance of the attributes for pre-packed sliced cheese choice separated by country.

口: Hungary; $\square$ : Romania; $\square$ : Spain

"Natural preservatives" had significantly positive impact in the pre-packed sliced cheese choice - mainly in Romania - (Hypothesis 3 is confirmed), while "artificial" had significantly negative effect in all countries (Table 2). In Spain and in Hungary the presence of the "packaging gases" had high positive impact on the preference of pre-packed cheese. Price with $10 \%$ above the average had positive influence on pre-packed cheese choice in Hungary and Spain, while 20\% above the average had negative influence in the three analysed countries (Hypothesis 4 is partly rejected).

Table 2. Utility values and standard error for the contribution of the factors to consumer choice of pre-packed sliced cheese separated by country

\begin{tabular}{llcccccc}
\hline \multirow{2}{*}{ Factor } & Level & \multicolumn{2}{c}{ Hungary } & \multicolumn{2}{c}{ Spain } & \multicolumn{2}{c}{ Romania } \\
& & Utility & SD & Utility & SD & Utility & SD \\
\hline Preservative & Natural & $1.390^{\mathrm{cx}}$ & 0.147 & $1.482^{\mathrm{bx}}$ & 0.128 & $1.712^{\mathrm{ax}}$ & 0.164 \\
& Artificial & $-1.390^{\mathrm{ay}}$ & 0.147 & $-1.482^{\mathrm{by}}$ & 0.128 & $-1.712^{\mathrm{cy}}$ & 0.164 \\
\multirow{2}{*}{ Packaging gases } & Presence & $0.392^{\mathrm{bx}}$ & 0.145 & $0.636^{\mathrm{ax}}$ & 0.113 & $0.168^{\mathrm{cx}}$ & 0.176 \\
& Absence & $-0.392^{\mathrm{by}}$ & 0.145 & $-0.636^{\mathrm{cy}}$ & 0.113 & $-0.168^{\mathrm{ay}}$ & 0.176 \\
\multirow{2}{*}{ Price } & Average & $-0.152^{\mathrm{by}}$ & 0.250 & $0.583^{\mathrm{ax}}$ & 0.208 & $0.590^{\mathrm{ax}}$ & 0.278 \\
& $+10 \%$ & $0.456^{\mathrm{ax}}$ & 0.185 & $0.098^{\mathrm{by}}$ & 0.140 & $-0.030^{\mathrm{cy}}$ & 0.192 \\
& $+20 \%$ & $-0.304^{\mathrm{az}}$ & 0.169 & $-0.680^{\mathrm{cz}}$ & 0.148 & $-0.560^{\mathrm{bz}}$ & 0.202 \\
\hline
\end{tabular}

Mean utilities with different superscript letters within a row ${ }^{(a, b, c)}$ and with different superscript letters within each factor and country $(\mathrm{x}, \mathrm{y}, \mathrm{z})$ differ significantly $(\mathrm{P} \leq 0.05)$. 


\subsection{Relative importance and utility values of chips}

"Preservatives" had dominant importance in the choice decisions of chips (Hypothesis 1 is confirmed) (Fig. 2). Comparing the relative importance values amongst the countries - as it was perceived from the results of pre-packed sliced cheese and in the findings of Szücs and co-workers (2012) - it can be noted that "preservatives" had higher importance in Hungary and Romania than in Spain, while "packaging gases" resulted higher importance for the Romanian and the Spanish participants than for the Hungarian ones. Therefore, on the basis of the results of the chips Hypothesis 2 is confirmed. "Price" was found to be a less important factor for the Romanian than for the Hungarian and the Spanish participants in the studies.

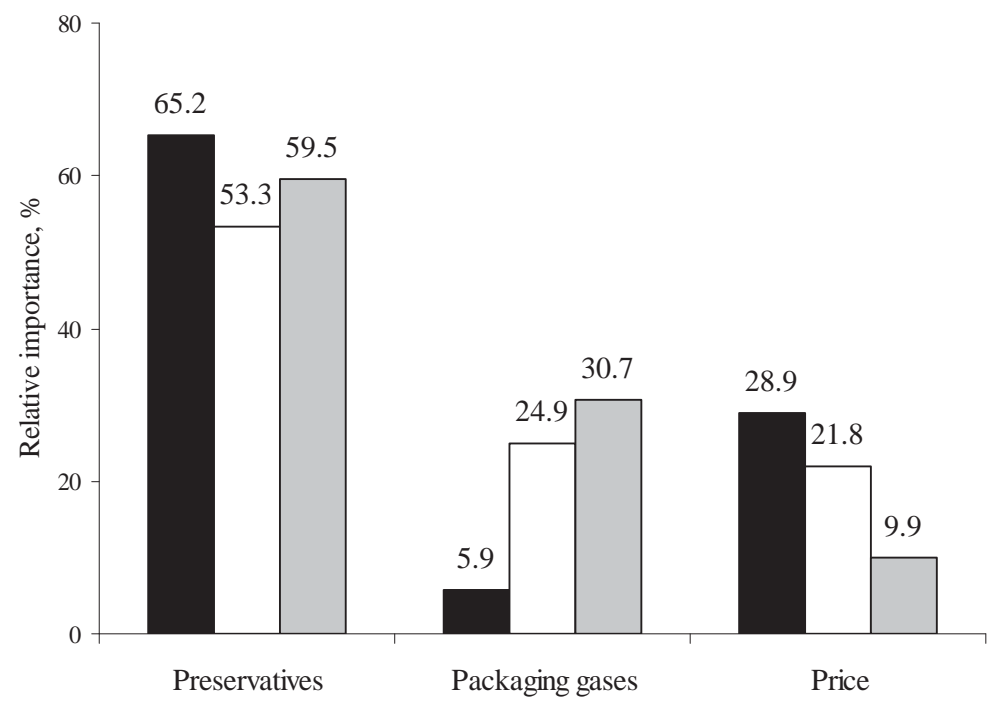

Fig. 2. Relative importance of the attributes for chips choice separated by country ㅁ: Hungary; $\square$ : Romania; $\square$ : Spain

"Natural preservatives" had significantly positive impact on the choice intention of chips, and "artificial preservatives" had significantly negative impact (Hypothesis 3 is confirmed) (Table 3). Presence of "packaging gases" had highly positive effect in the selection of chips in Spain and Romania. However, it had negative impact on the decision in Hungary. "Price" $10 \%$ above the average had positive impact in these three countries, while "price" $20 \%$ above the average had significantly negative impact on the choice in Hungary and Spain. The positive willingness to buy presented by a previous study (SzüCs et al., 2012) was perceived just in the case of $+10 \%$, thus Hypothesis 4 is partly rejected. 
Table 3. Utility values and standard error for the contribution of the factors to consumer choice of chips separated

\begin{tabular}{|c|c|c|c|c|c|c|c|}
\hline \multirow[t]{2}{*}{ Factor } & \multirow[t]{2}{*}{ Level } & \multicolumn{2}{|c|}{ Hungary } & \multicolumn{2}{|c|}{ Spain } & \multicolumn{2}{|c|}{ Romania } \\
\hline & & Utility & SD & Utility & SD & Utility & $\mathrm{SD}$ \\
\hline \multirow[t]{2}{*}{ Preservative } & Natural & $1.737^{\mathrm{ax}}$ & 0.143 & $1.498^{\mathrm{bx}}$ & 0.128 & $1.353^{\mathrm{cx}}$ & 0.160 \\
\hline & Artificial & $-1.737^{\mathrm{cy}}$ & 0.143 & $-1.498^{\text {by }}$ & 0.128 & $-1.353^{\mathrm{ay}}$ & 0.160 \\
\hline \multirow[t]{2}{*}{ Packaging gases } & Presence & $-0.156^{\text {by }}$ & 0.146 & $0.700^{\mathrm{ax}}$ & 0.115 & $0.698^{\mathrm{ax}}$ & 0.202 \\
\hline & Absence & $0.156^{\mathrm{ax}}$ & 0.146 & $-0.700^{\text {by }}$ & 0.115 & $-0.698^{\text {by }}$ & 0.202 \\
\hline \multirow[t]{3}{*}{ Price } & Average & $0.586^{\mathrm{ax}}$ & 0.226 & $0.533^{b x}$ & 0.209 & $-0.124^{\mathrm{cy}}$ & 0.312 \\
\hline & $+10 \%$ & $0.367^{\text {ay }}$ & 0.159 & $0.161^{\mathrm{cy}}$ & 0.142 & $0.287^{\mathrm{bx}}$ & 0.208 \\
\hline & $+20 \%$ & $-0.953^{\mathrm{cz}}$ & 0.170 & $-0.694^{\mathrm{bz}}$ & 0.147 & $-0.163^{\text {ay }}$ & 0.219 \\
\hline
\end{tabular}

Mean utilities with different superscript letters within a row ${ }^{(a, b, c)}$ and with different superscript letters within each factor and country ${ }^{(\mathrm{x}, \mathrm{y}, \mathrm{z})}$ differ significantly $(\mathrm{P} \leq 0.05)$.

\section{Conclusions}

"Preservatives" had an outstanding importance in both products' choice decisions in the analysed countries (Hypothesis 1 is confirmed), mainly in Hungary and Romania. Results point out that judgement of food additives on the basis of their origin ("natural"/"artificial") show stable and common feature, thus substitution of "artificial" preservatives with "natural" ones can influence the analysed countries consumers' food choice decisions favourably (Hypothesis 3 is confirmed).

The importance of "packaging gases" showed differences in these three countries (Hypothesis 2 is confirmed) and the foodstuffs, too. However, it can be noted that for the Spanish participants it had high importance in case of both foodstuffs. The presence of "packaging gases" had higher utility value for the Hungarian and Spanish participants in case of pre-packed cheese, and in case of chips for Spanish and Romanian respondents. It is noteworthy that Spanish participants rated the presence of "packaging gases" as a positive product characteristic in case of both foodstuffs, which can be due to the fact that in Spain the pre-packed products are common and they are aware of the advantages of these products (e.g. easy to handle, comfortable).

High level of willingness to buy additive-free foodstuffs found during the previous studies (Szücs et al., 2012) was not observed in the present study, just in the case of the average $+10 \%$ price (Hypothesis 4 is partly rejected). Furthermore - in contrast to some studies (Lappalainen et al., 1998; Honkanen \& Voldens, 2006; GFK, 2007) -, the "price" was less important factor in the shopping intentions than food additives, mainly the "preservatives". However, during the launching of any new product, it is important to take into consideration the "price", which can result in rejection.

Outstanding importance of food additives in the Hungarian consumers' shopping decision (GFK, 2007; MARIÁN et al., 2011; MARKETING INFO, 2013) was not observed, as well as consumer judgement of the foodstuffs from the point of view of food additives (prepacked sliced cheese was more favoured than chips) (TARNAVÖLGYI, 2009; SzÜcs \& BÁNÁTI, 2010) did not have relevant influence on the choice decision. However, the comparison of the 
countries' data showed notable differences, which can determine the direction of the product planning and development. Differences in the analysed countries' risk perception of food additives (EUROBAROMETER, 2006, 2010; SzÜCs et al., 2012) can be identified in the results of the present study, too. Members of the Hungarian and the Romanian sample showed higher rejection of the "artificial preservatives" and the presence of "packaging gases" than the Spanish participants (Hypothesis 5 is confirmed).

In the present study, consumer preferences were analysed in case of only two foodstuffs, with the help of three product characteristics, and in three European countries. Extension of the study onto other foodstuffs and factors, as well as involvement of other countries can help to identify the connection between the risk perception of certain foodstuffs and additives, furthermore, can point out new aspects.

\section{References}

Carrillo, E., Varela, P., Salvador, A. \& Fiszman, S. (2011): Main factors underlying consumers' food choice: A first step for the understanding of attitudes toward "healthy eating". J. Sens. Stud., 26, 85-95.

Eurobarometer (2006): Health and Food. Special Eurobarometer 246, p. 105.

Eurobarometer (2010): Food-related risks. Special Eurobarometer 354, pp.103, 111.

Eurobarometer (2013): Chemicals. Flash Eurobarometer, p. 95.

Farr, A., Tarcea, M., Ureche, R., Harko, Z. \& Dragoi, S. (2007): Atitudini, comportamente şi cunoştinţe ale studenţilor mureşeni legate de aditivii alimentari. (Students' attitude, behaviour, and knowledge about food additives in Mures region) Revista de Medicină şi Farmacie, 53, 208-214.

Food Standards Australia New Zealand (2003): Food labelling issues: Quantitative research with consumers. Evaluation report series no. 4. June 2003. pp. 8-9, Available at: http://www.foodstandards.gov.au/_srcfiles/ Part_1_with\%20App_A.pdf(last accessed: 9 December 2013)

GFK (2007): A vásárlóknak legfontosabb az élelmiszerek jó minősége (For shoppers the quality of the foodstuffs is the most important). Gfk Piaci Trend Hirlevél. XI, nov.-dec., 6 pages.

Grunert, K.G., Fernández-Celemín, L., Willis, J.M., Bonsmann, S.S. \& Nureeva, L. (2010): Use and understanding of nutrition information on food labels in six European countries. J. Public Health, 18 (3), 261-277.

Guerrero, L., Claret, A., Verbeke, W., Vanhonacker, F., Enderli, G., Sulmont-Rossé, C., Hersleth, M. \& GuÁRDIA, M.D. (2012): Cross-cultural conceptualization of the words Traditional and Innovation in a food context by means of shorting task and hedonic evaluation. Food Qual. Prefer., 25, 69-78.

Honkanen, P. \& Voldens, G. (2006): Russian consumers'food habits. Results from a qualitative study in Moscow. pp. 1-13. Available at: http://www.nofima.no/filearchive/Rapport $\% 2027-2006 \% 20$ Russian $\% 20$ consumers $\% 20$ food\%20habits.pdf (last accessed: 9 December 2013)

JEVŠnik, M., HLebeC, V. \& RAsPor, P. (2008): Consumers' awareness of food safety from shopping to eating. Food Control, 19, 737-745.

Kajanne, A. \& Pirttilä-Backman, A.M. (1999): Laypeople's viewpoints about the reasons for expert controversy regarding food additives. Public Underst. Sci., 8, 303-315.

LAKNER, Z. (2002): Adalékok a kozmetikai termékek piaci viszonyainak megismeréséhez. A kozmetikai és háztartásvegyipari termékek vásárlását befolyásoló tényezők vizsgálata. (Additives for the recognition of the cosmetics' market relations. Analysis of the factors influencing the shopping of cosmetics and domestic-chemical industry products.) Olaj, Szappan, Kozmetika, 51 (3), 116-122.

Lappalainen, R., Kearney, J. \& Gibney, M. (1998): A Pan EU survey of consumer attitudes to food, nutrition and health: An overview. Food Qual. Prefer., 9, 467-478.

Marián, A., Molnár, Zs., Erdey, J., Avramucz, A. \& Palotás, G. (2011): Healthy eating in consumers' consciousness I. Hung. J. Food Nutr. Marketing, 1-2, 25-34.

MARKeting INFO (2013): Jobban odafigyelünk az élelmiszerek összetételére. A tápérték helyett a tartósítószer miatt aggódunk. (We take more attention on foodstuffs' composition. Instead of nutritional value we worry about preservatives). Available at: http://www.marketinginfo.hu/tanulmanyok/essay.php?id=2003 (last accessed: 9 December 2013)

McCarthy, M., Brennan, M., Kelly, A.L., Ritson, C., De Boer, M. \& Thompson, N. (2007): Who is at risk and what do they know? Segmenting a population on their food safety knowledge. Food Qual. Prefer., 18, $205-217$.

Acta Alimentaria 43, 2014 
MediÁn (2009): A közvélemény a szintetikus anyagok egészségügyi hatásairól (Public opinion about the synthetic substances' health effect). Available at: http://www.median.hu/object.7e846e98-f731-4d2c-9fa73ec7f89e9836.ivy (last accessed: 9 December 2013)

North, E. \& DE Vos, R. (2002): The use of conjoint analysis to determine consumer buying preferences: A literature review. J. Fam. Ecol. Cons. Sci. (JFECS), 30, 32-39.

Ozer, B.C., Duman, G. \& CABuK, B. (2009): Turkish preschool staff's opinions about hormones, additives and genetically modified foods. Procd. Soc. Behv., 1, 1734-1743.

RyAN, M. \& FARRAR, S. (2000): Using conjoint analysis to elicit preferences for health care. BMJ. 320, 1530-1532.

Schafer, E., Schafer, R.B., Bultena, G.L. \& Hoiberg, E.O. (1993): Safety on the U.S. food supply: consumer concerns and behaviour. J. Consum. Stud. Home Econ., 17, 137-144.

Shim, S.M., Seo, S.H., Lee, Y., Moon, G.I., Kim, M.S. \& Park, J.H. (2011): Consumers' knowledge and safety perceptions of food additives: Evaluation on the effectiveness of transmitting information on preservatives. Food Control, 22, 1054-1060.

SzüCs, V. \& BÁNÁTI, D. (2010): Consumer knowledge and judgement of food additives in Hungary on the basis of questionnaire survey. $7^{\text {th }}$ International Conference of PhD Students. Miskolc, Hungary. $8^{\text {th }}-12^{\text {st }}$ August, 2010. pp. 41-46.

Szücs, V., Szabó, E., Tarcea, M., Szavuj, J., Claret, A., Guerrero L. \& Bánáti, D. (2012): Knowledge and judgement of food additives in three European countries. $6^{\text {th }}$ Central European Congress on Food. Novi Sad, Serbia. $23^{\text {rd }}-26^{\text {th }}$ May, 2012. pp. $1176-1180$.

TARNAVÖLGYI G. (2003): Analysis of consumers' attitudes towards food additives using focus group survey. Agriculturae Conspectus Scientificus, 68 (3), 193-196.

TARNAVÖLGYI, G. (2009): Az élelmiszer-adalékanyagok szakmai és fogyasztói megitélése. (Professional and consumer attitudes towards food additives). PhD Dissertation, pp. 103-105.

Unusan, N. (2007): Consumer food safety knowledge and practices in the home in Turkey. Food Control, 18, 45-51.

Wardle, J., Waller, J., Burnswicg, N. \& Jarvis, M.J. (2001): Awareness of risk factors for cancer among British adults. Public Health, 115, 173-174. 